\title{
The effect of distributive justice on intention to pay zakat through zakat institutions using affective and cognitive trust as intervening variables
}

\author{
Arsyad Abror, Ataina Hudayati* \\ Departmen of Accounting, Universitas Islam Indonesia, Yogyakarta, Indonesia \\ *Corresponding author: ataina.hudayati@uii.ac.id
}

\section{Keywords: \\ Distributive justice, affective trust, cognitive trust, intention to pay zakat}

\author{
Article History \\ Received: 26 September 2019 \\ Accepted: 6 January 2020 \\ Published: 23 January 2020 \\ DOI: \\ 10.20885/JEKI.vol6.iss1.art3 \\ JEL: A10, E44, G21, Z12
}

\begin{abstract}
The purpose of this study was to examine the effect of distributive justice on the intention to pay zakat through Zakat Institutions (ZIs), using affective trust and cognitive trust as intervening variables. Data collection techniques through the distribution of questionnaires to 272 Muslims in Yogyakarta. Data analysis using Structural Equation Modeling (SEM) with SmartPLS software version 3.2. The findings show that the distributive justice has a positive effect on intention to pay zakat through ZIs, as well as has a positive effect on affective and cognitive trust. In addition, affective and cognitive trust has a positive effect on intention to pay zakat through ZIs. The results of the study also show that affective and cognitive trust are intervening variables on the relationship between distributive justice and the intention to pay zakat through ZIs.
\end{abstract}

\section{Cite this:}

Abror. A., \& Hudayati. A. (2020). The effect of distributive justice on intention to pay zakat through zakat institutions using affective and cognitive trust as intervening variables. Jurnal Ekonomi dan Kenangan Islam. 6(1), 24-33. DOI: 10.20885/JEKI.vol6.iss1.art3

\section{Introduction}

Indonesia is a country in which the population is mostly Muslim. To improve the effectiveness of zakat management, the government and the community established the Zakat Institution (ZI). BAZNAS states that currently there are 34 provincial BAZNAS, 18 national-scale Amil Zakat Institutions, 500 regency/municipal BAZNAS, and 19 International Amil Zakat Institutions (BAZNAS, 2018b). The considerable number of ZIs is expected to increase the amount of zakat collected each year. Nevertheless, the realization of zakat is still far from the existing potential. Based on data, the potential of zakat in Indonesia reached IDR 286 Trillion in 2015 but the collection in that year only reached IDR 3.65 Trillion (BAZNAS, 2018a). The low realization of zakat can be caused by the fact that Indonesian Muslims lack of awareness of zakat obligations, they mostly pay zakat individually without zakat institutions, or there is a large amount of zakat fund collected by zakat institutions in areas but not monitored.

Data showing that the realization of zakat is still far from what is expected should encourage ZIs to improve the quality of zakat management so as to increase public trust in ZIs. Regarding the fact that public trust in ZIs influences the intention to pay zakat through ZIs, there are several studies that examined the effect of trust in ZIs on the intention to pay zakat, for examples Sidiq (2015), Azimah (2016), Yunus (2016), Satrio and Siswantoro (2016).

Although trust has been widely studied as a factor that influences the intention to pay zakat, the concept of trust can actually be divided into cognitive trust and affective trust. Not many studies have examined the effect of cognitive and affective trust on the intention to pay 
zakat through ZIs except for a research conducted by Ikhwanda and Hudayati (2019). Therefore, this study also examined the effect of these two types of trust. The difference between this research and that of Ikhwanda and Hudayati (2019) is that in Ikhwanda and Hudayati (2019) both trusts were influenced by transparency and accountability, whereas this study predicted that both trust were influenced by the distributive justice of zakat. To expand Ikhwanda and Hudayati (2019) this study also examined the role of cognitive and affective trust as an intervening variable on the relationship between distributive justice and intention to pay zakat through ZIs. Ikhwanda and Hudayati (2019) only examined the indirect effect of transparency and accountability on the interest in paying zakat through zakat institutions. This paper examined both the direct and indirect effects of the distributive justice of zakat institutions on the intention to pay zakat.

Justice is an Islamic value that is emphasized in the Qur'an. There are so many verses in the Qur'an that emphasize that we must be fair (An-Nisa:58; An-Nisa:135; Al-Maidah:8; AlMaidah:42; Al-An'am:152; Al-A'raf:29-30). Even so, it has not been found or perhaps not many research projects have examined the effect of justice on the interest of muzakki in paying zakat through zakat institutions. Research related to the fairness of the distribution of zakat had been conducted by Utamy (2015). Utamy (2015) only described the concept of distributive justice of wealth in Islam. Research that examined the effect of distributive justice on the intention to pay zakat through ZIs has not been found and this is why this research was conducted.

Justice theory was used as a basis for explaining the effect of justice on cognitive trust, affective trust and intention to pay zakat through zakat institutions. In this study, the theory of justice requires that in allocating zakat to the eighth mustahiq, zakat institutions apply the principle of justice. Even in Islam, justice is a behavior that is highly emphasized. Winthrop (1978) explains the concept of justice based on the Theory of Justice developed by Aristotle. According to Aristotle, the concept of justice is divided into two concepts namely distributive and corrective justice.

The concept of distributive justice states that all people must obtain the same rights to the distribution of prosperity. Distributive justice is a form of justice related to the magnitude of the results of sharing, giving and exchanging resources received by someone from another person or from a group or institution. Corrective justice is justice that provides the principles applied in a court when a dispute occurs over a contract. This research used the concept of distributive justice. Related to the distribution of zakat according to fiqh, of the eight groups of mustahiq mentioned above, there are conditions that serve as benchmarks for someone categorized as mustahiq, namely Muslim, unable to work, living in zakat-producing areas, and not descendants of the Bani Hashim and the Bani Muthalib.

Trust can be defined as willingness of one party to deal with another party based on the belief that the other party is competent, open, caring, and reliable (Zur, Leckie, \& Webster, 2012). Johnson dan Grayson (2005) explain that the concept of trust can be classified into cognitive and affective trust. Cognitive trust is trust by relying on competence and reliability possessed by other parties. Meanwhile affective trust is related to how an object feels, where the main component is emotional factor. Trust based on cognition breeds trust or distrust of others as a form of decision based on rationality. Meanwhile affective trust comes from deep emotional factors when establishing relationships with other parties (Ergeneli, Ari, \& Metin, 2007).

The purposes of this study are: analyzing the effect of distributive justice on the intention to pay zakat through ZIs; analyzing the effect of distributive justice on affective and cognitive trust; assessing the role of affective and cognitive trust as an intervening variable on the relationship between distributive justice and the intention to pay zakat through ZIs. 


\section{Research Method}

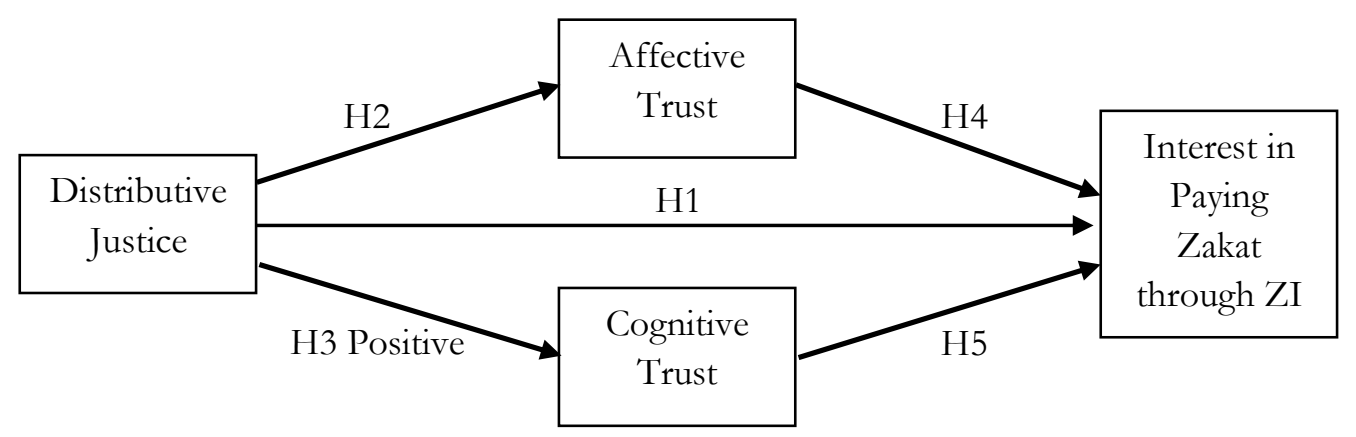

Figure 1. Research Model

The respondents of this study were Muslims in Yogyakarta. The respondents were selected using a random sampling method that provides equal opportunity to each member of the population to become a respondent. The sample criteria used in this study were: Muslim and baligh; and domiciled in the Special Region of Yogyakarta. The distribution was carried out directly in mosques in the local government, where the local government already has regulations regarding zakat payment through Baznas. In addition to direct distribution, data collection was done indirectly through Google forms that were distributed via instant messenger media. From the data collection process, 272 questionnaires were collected.

In addition, the respondents of the research conducted by Ikhwanda and Hudayati (2019) were only muzakki from the Amil Zakat Agency (BAZNAS) Yogyakarta. The respondents of this study were people who paid zakat through zakat management organizations (not only BAZNAS) and people who never paid zakat through zakat management organizations. The benefit of conducting a research into the determinants of Muslims intentions that have and have never paid zakat through zakat institutions is that zakat institution managers and various interested parties can focus on how to make people who pay zakat through zakat institutions continue to trust zakat management organizations to manage their zakat. As for the people who do not pay zakat through zakat institutions, in the coming years they are expected to be interested in paying zakat through zakat institutions.

However, the use of muzakki who has never paid zakat as research respondents has weaknesses because it is possible that the emotional intimacy between muzakki and zakat institutions is very low. Nevertheless, the emotional intimacy can be obtained when muzakki is involved in other activities carried out by zakat institutions or when the family or relatives of muzakki are involved as zakat institution organizers. In addition, Muslims who have never paid zakat can be involved as research respondents because affective trust was measured for example with the following question: "As a muzaki, I have the freedom to give my ideas and thoughts to zakat institutions. Zakat institutions will help the difficulties I face related to zakat payments. If I have a problem regarding zakat payment, zakat institution will give a good response ".

In this study the dependent variable was the intention to pay zakat through ZIs. Intention to pay zakat was defined as willingness of muzakki or prospective muzakki to pay zakat through ZIs. The variable of intention to pay zakat was measured using three items of the questionnaires in a previous study conducted by Ikhwanda and Hudayati (2019).

The independent variable was distributive justice of which the measurement instruments contained: ZIs determined mustahiq according to Islamic law; ZIs had particular criteria for determining mustahiq who received zakat and muzakki was informed clearly; ZIs had financial planning, recording, and management to allocate and distribute zakat; ZIs had a consumptive and productive zakat distribution program and muzakki was clearly informed; productive and consumptive zakat distribution program was designed in accordance with sharia principles; the 
distribution of zakat by ZIs was based on the priority of justice, and in regions near with muzakki; the board of directors of ZIs had rules to prevent personal interest during zakat distribution. The research instrument was developed based on indicators of the principle of distributive justice of zakat compiled by Beik et al., (2016). The instrument was measured using seven question items.

In this research, the intervening variable was trust. As explained previously in the literature review of this study, trust was divided into two, namely affective and cognitive trust. The measurement of this variable was based on a questionnaire developed by Johnson and Grayson (2005) which was used in Ikhwanda and Hudayati (2019). Affective trust was measured using five items while cognitive trust using six items. All the questionnaires were measured using a 4-point Likert scale starting with strongly disagree, disagree, agree and strongly agree.

\section{Results and Discussion}

\section{Descriptive analysis}

The descriptive statistics of the respondents is shown in Table 2-Table 5. There were 272 Muslim respondents in this study who lived in the Special Region of Yogyakarta. The respondents were selected by direct questionnaire distribution, i.e. 128 respondents by visiting several mosques in several areas in the Special Region of Yogyakarta and 48 respondents by visiting Sleman Regional Government, as well as indirect questionnaire distribution through Google form which obtained 95 respondents.

Table 2. Respondents by Gender

\begin{tabular}{lcc}
\hline \multicolumn{1}{c}{ Gender } & Number (person) & Percentage \\
\hline Male & 199 & $73,17 \%$ \\
Female & 73 & $26,83 \%$ \\
\hline Total & $\mathbf{2 7 2}$ & $\mathbf{1 0 0} \%$ \\
\hline
\end{tabular}

Source: Data processing results, 2019

It can be seen from Table 2 that the respondents in this study were dominated by men (199 males and 73 females). In fact, it is understandable that the questionnaire distribution in several mosques directly affected the gender of the respondents to be dominated by males.

Based on the description in Table 3, most of the respondents in this study were $\leq 25$ years old.

Table 3. Respondents by Age

\begin{tabular}{lcc}
\hline \multicolumn{1}{c}{ Age } & Number (Person) & Percentage \\
\hline$\leq 25$ year & 114 & $41,91 \%$ \\
26 - 35 year & 76 & $27,94 \%$ \\
36 - 45 year & 32 & $11,76 \%$ \\
46 - 55 year & 30 & $11,02 \%$ \\
$\geq 56$ year & 20 & $7,35 \%$ \\
\hline Total & $\mathbf{2 7 2}$ & $\mathbf{1 0 0} \%$ \\
\hline
\end{tabular}

Source: Data processing results, 2019

Based on Table 4, the respondents were dominated by those who lived in Sleman Regency, i.e. 162 people from a total of 272 respondents with a percentage of 59.55\% (more than half of the respondents). This is due to the fact that the direct questionnaire distribution conducted by the researchers was done in the Regional Government of Sleman Regency and several mosques in Sleman. 
Table 4. Respondents Based on Domicile

\begin{tabular}{lcc}
\hline \multicolumn{1}{c}{ Regency/City } & Number (person) & Percentage \\
\hline Bantul & 31 & $11,39 \%$ \\
Gunung Kidul & 9 & $3,30 \%$ \\
Kota Yogyakarta & 46 & $16,91 \%$ \\
Kulon Progo & 24 & $8,82 \%$ \\
Sleman & 162 & $59,55 \%$ \\
\hline Total & 272 & $100 \%$ \\
\hline
\end{tabular}

Source: Data processing results, 2019

Table 5. Characteristics of Respondents Based on Already or Never Paying Zakat through ZI

\begin{tabular}{lcc}
\hline & Number (person) & Percentage \\
\hline Already & 123 & $45,22 \%$ \\
Never & 149 & $54,78 \%$ \\
\hline Total & $\mathbf{2 7 2}$ & $\mathbf{1 0 0} \%$ \\
\hline
\end{tabular}

Source: Data processing results, 2019

Table 5 shows that 123 respondents paid zakat through zakat institutions while 149 respondents never paid zakat through zakat institutions.

\section{Testing Measurement Model}

Testing measurement model explained in Table 6.

Table 6. Cross Loading

\begin{tabular}{ccccc}
\hline Item & JUSTICE & INTENTION & AFFECTIVE & COGNITIVE \\
\hline Just.1 & $\mathbf{0 , 8 0 8}$ & 0,238 & 0,474 & 0,484 \\
\hline Just.2 & $\mathbf{0 , 7 7 5}$ & 0,268 & 0,422 & 0,503 \\
\hline Just.3 & $\mathbf{0 , 8 2 9}$ & 0,292 & 0,500 & 0,559 \\
\hline Just.4 & $\mathbf{0 , 7 7 9}$ & 0,313 & 0,494 & 0,467 \\
\hline Just.5 & $\mathbf{0 , 7 7 8}$ & 0,292 & 0,500 & 0,493 \\
\hline Just.6 & $\mathbf{0 , 7 5 9}$ & 0,215 & 0,478 & 0,434 \\
\hline Int.1 & 0,435 & $\mathbf{0 , 8 7 4}$ & 0,414 & 0,666 \\
\hline Int.2 & 0,241 & $\mathbf{0 , 9 0 2}$ & 0,303 & 0,538 \\
\hline Int.3 & 0,221 & $\mathbf{0 , 8 9 9}$ & 0,288 & 0,555 \\
\hline Aff.1 & 0,503 & 0,334 & $\mathbf{0 , 8 7 3}$ & 0,483 \\
\hline Aff.2 & 0,568 & 0,340 & $\mathbf{0 , 8 9 6}$ & 0,503 \\
\hline Cog.1 & 0,658 & 0,381 & 0,546 & $\mathbf{0 , 7 1 3}$ \\
\hline Cog.2 & 0,383 & 0,395 & 0,357 & $\mathbf{0 , 7 0 9}$ \\
\hline Cog.3 & 0,517 & 0,545 & 0,433 & $\mathbf{0 , 8 3 0}$ \\
\hline Cog.4 & 0,465 & 0,555 & 0,414 & $\mathbf{0 , 7 8 5}$ \\
\hline Cog.5 & 0,389 & 0,543 & 0,384 & $\mathbf{0 , 7 6 6}$ \\
\hline Cog.6 & 0,411 & 0,598 & 0,401 & $\mathbf{0 , 7 6 5}$ \\
\hline
\end{tabular}

Source: Data processing results, 2019

At this stage, measurement tests were carried out to determine the validity and reliability of the research model, including: convergent validity, discriminant validity, and composite reliability. The convergent validity test results (Table 6 ) showed that all the question items had a loading factor $>0.7$. It can be concluded that all these items were valid. As explained in the research method, five items are used to measure affective trust. Even so, three items had loading less than 0.7 and were deleted. 
The next stage was to test the validity of the measurement using discriminant validity by looking at the cross loading of each item. The results of the study showed that the correlation between the measurement items and their constructs was higher than that of other block constructs. This showed that each construct measurement item was appropriate in measuring the construct and proved that the discriminant validity of all the constructs was valid. Then, the validity test was fulfilled.

Reliability tests were carried out to prove that each construct measurement item was accurate, precise, and consistent. This can be done by looking at Cronbach 's alpha and composite reliability $>0.7$ or seen from the average variance extracted (AVE) $>0.5$. The results of the study showed that each construct had a Cronbach's alpha and composite reliability $>0.7$ and Average Variance Extracted (AVE) $>0.5$, so it can be concluded that the constructs in the measurement model of this study were reliable and valid.

\section{Hypothesis Testing}

As explained in the previous chapter, testing of structural models (Inner Modeling) was used for hypothesis testing. Before hypothesis testing, Table 7 first explains the $\mathrm{R}$ Square of all the dependents variables.

Table 7. R Square

\begin{tabular}{ccc}
\hline Variable & R Square & R Square Adjusted \\
\hline Affective Trust & 0,369 & 0,366 \\
Cognitive Trust & 0,388 & 0,386 \\
Intention to pay Zakat & 0,451 & 0,445 \\
\hline
\end{tabular}

Source: Data processing results, 2019

Table 8 explains path coefficient and T-statistics to determine the relationship between variables, which in this case by doing bootstrapping method. The decision to accept or reject the proposed hypothesis was done by looking at T-Statistics and P-Value with a significance of TStatistics $>1.96$ and P-Value $<0.05$. Table 6 shows that all the T-Statistics $>1.96$ and $p$ value of 0.000 , indicating that hypotheses 1-5 were supported.

Table 8. Path Coefficient and T-Statistics

\begin{tabular}{lccc}
\hline \multicolumn{1}{c}{ Relationship } & Loadings & $\begin{array}{c}\text { T- } \\
\text { Statistics }\end{array}$ & P Values \\
\hline Justice - Intention to pay zakat & 0,344 & 4,364 & 0,000 \\
Justice - Affective Trust & 0,607 & 7,671 & 0,000 \\
Justice - Cognitive Trust & 0,623 & 8,893 & 0,000 \\
Affective Trust - Intention to & 0,705 & 8,109 & 0,000 \\
pay zakat & & & 0.000 \\
Cognitive Trust - Intention to & 0,714 & 10,119 & \\
pay zakat & & & \\
\hline
\end{tabular}

Source: Data processing results, 2019

\section{Testing of Intervening Variables}

Testing the role of trust as an intervening variable was done by Sobel Test. The value of the sobel statistical test on the influence of affective trust in mediating the relationship between distributive justice and intention to pay zakat was 104.5541 which is very significant with a probability of 0.000. The sobel statistic test on the influence of cognitive trust in mediating the relationship between distributive justice and intention to pay zakat was 110.0376 which is very significant with a probability of 0.000 . Thus, it can be concluded that cognitive and affective trust mediated the 
relationship between distributive justice and the intention to pay zakat through ZIs. The findings of this study implied that the distributive justice of zakat had an indirect effect on the intention to pay zakat and the indirect effect occurred through cognitive and affective trust variables. Nevertheless, the results of the study of the direct effect of distributive justice on the intention to pay zakat also showed a significant positive effect. Thus, it can be concluded that the intervening variable had partial mediation.

The results of the study showed that the distributive justice of zakat has a significant positive effect on the intention to pay zakat through ZIs. This result is in line with research conducted by Churiyah and Wiradani (2011), stating that distribution management is a factor that needs to be considered by muzakki to determine the choice of paying zakat through ZIs. In addition, Kiryanto and Khasanah ( 2013) who found that governance (including the distribution of zakat) has a positive effect on motivation to pay income zakat.

Several other studies have shown that the credibility of ZIs is a determining factor that is considered to increase people's awareness of paying zakat through ZIs. The distributive justice of zakat becomes an indicator that measures the level of muzakki's perception of the credibility of ZIs (Mustafa et al., 2013; Perbawa \& Abdullah, 2016; Azman \& Bidin, 2015; Kiryanto \& Khasanah, 2013).

The study results also showed that distributive justice has a significant positive effect on affective trust and the results of this study support the opinion of Mustafa et al. (2013) and Kiryanto and Khasanah (2013) which proved that distributive justice has an effect on increasing trust in ZIs. Distributive justice is a determining factor in making muzakki feel safe when paying zakat through ZIs (Kiryanto \& Khasanah, 2013). Feeling secure becomes very important when it is associated with the management of entrusted funds, especially to nonprofit-oriented organizations. Feeling secure will enhance and influence the perception of muzakki on ZIs (Azman \& Bidin, 2015).

As with affective trust, the results of the study also showed that distributive justice has a significant positive effect on affective trust. These results support the research of Mustafa et al. (2013) and Kiryanto and Khasanah (2013) which stated that the distributive justice of ZIs in distributing zakat has a positive effect on muzakki's trust in ZIs. This means that when ZIs distribute zakat justly, it will increase muzakki's trust that ZIs are competent and professional in distributing zakat.

The results of this study showing that affective trust has a significant positive effect on intention to pay zakat through ZIs support several previous studies (Sidiq, 2015; Satrio \& Siswantoro, 2016; Yunus, 2016; Setiawan, 2017). In contrast to previous studies that found the effect of trust on intention to pay zakat, this study found the influence of affective trust on intention to pay zakat. The results of this study also support Ikhwanda and Hudayati (2019), showing that affective trust has a significant positive effect on the intention to pay zakat through ZIs.

The loading value of the relationship between affective trust and the intention to pay zakat was very high (0.705) indicating that the respondents had a fairly positive emotional intimacy with ZIs. This positive emotional relationship arises because they feel secure comfortable when establishing a relationship with ZIs when paying zakat. The feeling of security and comfort leads to a positive perception of ZIs thus resulting in motivation and awareness of paying zakat through ZIs. Motivation and awareness are also able to influence the people around them, thus resulting in willingness to entrust the management of zakat to ZIs.

In addition, a positive emotional relationship between the managers of ZIs and muzakki that will create a sense of security and comfort, is also influenced by the intensity of relationships and communication that exist. Therefore, in terms of building affective trust, it is necessary for ZIs to have a special training program for their managers to have a personal character who is friendly and charming to establish communication with the muzakki. 
Cognitive trust has a significant positive effect on the intention to pay zakat through ZIs, as evidenced by a high loading value (0.714) and T-Statistics $10.119>1.96$. These results support previous research conducted by Sidiq, (2015); Satrio \& Siswantoro, (2016); Yunus, (2016); Setiawan, (2017) who stated that trust influences the intention to pay zakat. The results of the study also support a study by Ikhwanda and Hudayati (2019) who specifically divided trust into affective trust and cognitive trust and found that cognitive trust has a positive effect on intention to pay zakat through ZIs.

The results of the study indicated that affective and cognitive trust are the intervening variables of the influence of distributive justice on the intention to pay zakat, and these variables have partial mediation. This means that distributive justice can directly affect the intention to pay zakat. In addition, distributive justice can influence the intention to pay zakat through cognitive and affective trust. That means that there are three things that can increase the intention to pay zakat through ZIs, namely distributive justice, affective trust and cognitive trust.

\section{Conclusion}

The results of the data analysis showed that all of the research hypotheses were supported. The findings of this study have implications for various parties related to zakat management. Thus, these results need to be considered for zakat management in determining and focusing on management priorities to create management that is trusted by muzakki by making the best efforts to distribute zakat based on the principles of justice.

The results of the study have several implications for the management of ZIs. The managers of ZIs should prioritize building a good image of the institutions and uphold the principle of justice in managing zakat distribution. This policy also needs to be socialized to every muzakki. When muzakki understands the intention of zakat managers to manage zakat professionally, muzakki's intention to pay zakat through ZIs will increase. In addition, ZIs can create special programs or training to improve the communication skills of their managers in order to build good relationship and emotional intimacy with their muzakki, so as to create a sense of security and comfort for muzakki when paying zakat through ZIs.

For future researchers who want to conduct research on the same topic, it is necessary for them to pay attention to data collection methods. When questionnaire distribution method is used, it is necessary to pay attention to an even distribution process for each district. In fact, one of the weaknesses of this study is that the questionnaires were not distributed evenly to each district in the study area, so one district was given more questionnaires than others because this region was the target of the zakat distribution program by ZIs. Thus, there were presumably still more people classified as mustahiq than muzakki.

\section{References}

Azimah, N. H. (2016). Azimah, N. H. (2016). Pengaruh religiusitas, gaji dan kepercayaan terhadap minat muzakki membayar zakat di badan amil zakat nasional (BAZNAS) kabupaten Gresik. Theses. UIN Sunan Ampel, Surabaya. Retrieved from: http://digilib.uinsby.ac.id/9346/

Azman, F. M. N., \& Bidin, Z. (2015). Factors influencing zakat compliance behavior on saving. Internatioanl Journal of Business and Social Research, 5(1), 118-128. DOI: $\underline{10.18533 / \text { ijbsr.v5i1.688 }}$

BAZNAS. (2018a). Outlook qakat Indonesia 2018. Pusat Kajian Strategis Badan Amil Zakat Nasional (BAZNAS). Jakarta: BAZNAS. Retrieved from: file://C:/Users/User/AppData/Local/Packages/Microsoft.MicrosoftEdge_8wekyb3d8 bbwe/TempState/Downloads/389299944-Outlook-Zakat-Indonesia-2018- 
pdf $\% 20(1) \cdot p d f$

BAZNAS. (2018b). Profil BAZNAS. Retrieved from http://baznas.go.id/profil

Beik, I. S., Hanum, H., Muljawan, D., Yumanita, D., Fiona, A., \& Nazar, J. K. (2016). Core principles for effective zakat supervision. Jakarta: BAZNAS. Retrieved from: file://C:/Users/User/AppData/Local/Packages/Microsoft.MicrosoftEdge_8wekyb3d8 bbwe/TempState/Downloads/Zakat $\% 20$ Core $\% 20$ Principles $\% 20$ -

$\% 20 Z C P \% 20$ Document $\% 20(1) \cdot p d f$

Churiyah, M., \& Wiradani, W. (2011). Faktor-faktor yang dipertimbangkan muzakki dalam menyalurkan zakat melalui yayasan amal sosial ash shohwah Malang. MODERNISASI, 8 (3), 233-246.. Retrived from: http://ejournal.unikama.ac.id/index.php/JEKO/article/view/788/574

Ergeneli, A., Ari, G. S. `\& Metin, S. (2007). Psychological empowerment and its relationship to trust in immediate managers. Journal of Business Research, 60(1), 41-49. DOI:10.1016/j.jbusres.2006.09.012

Farouk, A. U., Idris, M. K., \& Saad, R. A. J. (2018). Moderating role of religiosity on zakat compliance behavior in Nigeria. International Journal of Islamic and Middle Eastern Finance and Management, 11(3), 357-373. DOI: 10.1108/IMEFM-05-2017-0122

Ikhwanda, M. F., \& Hudayati, A. (2019). The influence of accountability, transparency, affective and cognitive trust toward the interest in paying zakat. Jurnal Akuntansi dan Auditing Indonesia, 23(1), 39-51. DOI: https://doi.org/10.20885/jaai.vol23.iss1.art5

Johnson, D., \& Grayson, K. (2005). Cognitive and affective trust in service relationships. Journal of Business Research, 58(4), 500-507. DOI: https://doi.org/10.1016/S0148-2963(03)001401

Kiryanto, K. \& Khasanah, V. N. (2013). Analisis karakteristik muzakki dan tata kelola LAZ terhadap motivasi membayar zakat penghasilan. Jurnal Akuntansi Indonesia, 2(1), 51-64. DOI:10.30659/jai.2.1.51-64

Mustafa, M. O. A., Mohamad, M. H. S., \& Adnan, M. A. (2013). Antecedents of zakat payer's trust in an emerging zakat sector: An exploratory Study. Journal of Islamic Accounting and Business Research, 4(1), 4-25. DOI: DOI: 10.1108/17590811311314267

Perbawa, A., \& Abdullah, H. R. (2016). Determinant factors of awareness for paying zakat on BAZNAS, Indonesia. International Humanistic Management Association Research Paper Series, 25. Retrieved from https://ssrn.com/abstract=2799446.

Saad, R. A. J., \& Haniffa, R. (2014). Determinants of zakat (islamic tax) compliance behavior. Journal of Islamic Accounting and Business Research, 5(2), 182-193. DOI:10.1108/JIABR-102012-0068

Satrio, E., \& Siswantoro, D. (2016). Analisis faktor pendapatan, kepercayaan dan religiusitas dalam mempengaruhi minat muzakki untuk membayar zakat penghasilan melalui lembaga amil zakat. Simposium Nasional Akuntansi XIX, 1(4), 308-315. Retrieved from: http://lib.ibs.ac.id/materi/Prosiding/SNA\%20XIX\%20(19)\%20Lampung\%202016/mak alah/083.pdf

Setiawan, F. (2017). Pengaruh religiusitas, kepercayaan dan reputasi terhadap minat muzakki dalam membayar zakat profesi. Theses. Universitas Muhammadiyah Surakarta, Surakarta. Retrieved from http://eprints.ums.ac.id/56679/18/09.\%20NASKAH\%20PUBLIKASI.pdf

Sidiq, H. A. (2015). Pengaruh pengetahuan zakat, tingkat pendapatan, religiusitas dan kepercayaan 
kepada organisasi pengelola zakat terhadap minat membayar zakat pada lembaga amil zakat: Studi kasus terhadap muzakki di fakultas agama Islam dan fakultas ekonomi dan bisnis universitas muhammadiyah Surakarta. Theses. Universitas Muhammadiyah Surakarta, Surakarta. Retrieved from: http://eprints.ums.ac.id/36839/4/03.\%20HALAMAN\%20DEPAN.pdf

Triyawan, A., \& Aisyah, S. (2016). Analisis faktor-aktor yang mempengaruhi muzakki membayar zakat di BAZNAS Yogyakarta. Islamic Economics Journal, 2(1), 53-69. DOI:10.21111/iej.v2i1.970

Utamy, H. R. (2015). Keadilan ekonomi dalam pendistribusian zakat oleh Badan Amil Zakat Nasional (BAZNAS) kabupaten Tanah Datar. Jurnal Tamwil, 1(2), 18. DOI: 10.31958/jtm.v1i2.324

Winthrop, D. (1978). Aristotle and theories of justice. The American Political Science Review, 72(4), 1201-1216. DOI: $10.2307 / 1954534$

Yunus, M. (2016). Analisis pengaruh kepercayaan, religiusitas dan kontribusi terhadap minat pedagang mengeluarkan zakat di baitul mal: Studi kasus pada pedagang pasar los Lhokseumawe. At-Tawassuth, 1(1), 95-124 Retrieved from: http://jurnal.uinsu.ac.id/index.php/tawassuth/article/view/365

Zur, A., Leckie, C., \& Webster, C. M. (2012). Cognitive and affective trust between Australian exporters and their overseas buyers. Australasian Marketing Journal, 20(1), 73-79. DOI:10.1016/j.ausmj.2011.08.001. 